\title{
Hubert Stys
}

\section{Elżbieta Znamierowska-Rakk, Federacja Slowian Poludniowych w polityce Bulgarif po II wojnie światowej. Korzemie, próby realizacji, upadek, Warszawa 2005, ss. 494}

Nakładem Wydawnictwa Neriton ukazała się znacznych rozmiarów monografia dotycząca koncepcji sfederowania państw bałkańskich po II wojnie światowej, co w praktyce zawęża się do planów połączenia Jugosławii z Butgarią. Ta tematyka, podobnie zreszta jak wiele innych związanych z Bałkanami, nie doczekała się w naszym kraju wyczerpujących badań, dlatego też cieszy każda nowa publikacja dotycząca tego regionu. Co do samej Bułgarii i jej losów politycznych po II wojnie światowej, istnieje kilka opracowań książkowych, ale ze względów oczywistych nie wyczerpują one całości tematyki bułgarskiej ${ }^{1}$.

Elżbieta Znamierowska-Rakk od ponad 20 lat zajmuje się tematami związanymi $\mathrm{z}$ historią Bułgarii XX wieku ${ }^{2}$, jej znajomošć historiografii i archiwaliów bułgarskich jest niezwykle szeroka i pozwala już na wstępie napisać, że praca przygotowana została dokładnie i fachowo. Archiwa sofijskie (partyjne, państwowe, ministerstwa spraw zagranicznych), wzbo-

' Pogłębione badania prowadził Jerzy Jackowicz, Partie opozycyjne w Bulgarii 1944-1948, Warszawa 1997, jak również Jerzy Tomaszewski, Bufgaria 1944-1971. Trudna droga do socjalizmu, Warszawa 1989, (podaję wybrane publikacje - H. S.), jak również Adam Koseski i Marek Żmigrodzki. Warto zwrócić uwagę na wspomnienia: N. Gančovski, Georgi Dymitrow: z notatnika sekretarza osobistego, Warszawa 1980.

${ }^{2}$ Dwie najważniejsze publikacje autorki dotyczące Bułgarii: Rozwój stosunków Butgarii z Grecja i Turcja po II wojnie światowej 1944-1975, Wrocław 1979; Sprawa Tracji Zachodniej w polityce bulgarskiej (1919-1947), Warszawa 1991. 
gacone materiałami z Wielkiej Brytanii (Public Record Office) i archiwaliami polskimi i czechosłowackimi, przy znajomości materiałów opublikowanych i opracowań to podstawa, na której autorka zbudowala swoja najnowszą publikację. Poprzez opracowania bułgarskie pośrednio korzysta $\mathrm{z}$ materiałów jugosłowiańskich, ale nie ma to negatywnego wpływu na prezentowany temat.

Federacja Slowian... ma uklad chronologiczny, podobnie zresztą jak wcześniejsze publikacje autorki. Podział na sześć rozdziałów jest czytelny, obejmuje poszczególne etapy rozwoju koncepcji federalizacyjnych. Pierwsze takie idee, powstające od schyłku XVIII wieku, przywołują na myśl obecne pomysty zjednoczeniowe w Europie. Wówczas - w XIX wieku - utworzenie federacji narodów bałkańskich wielu traktowało jako szanse na wydźwignięcie małych państw od zależności tureckiej, która determinowała większość działań politycznych w tym regionie. Dlatego w koncepcjach zjednoczeniowych zróżnicowanie narodowe, językowe czy religijne nie grały roli, do wspólnego państwa federacyjnego chciano włączać Rumunię, Bułgarię, Serbię, Grecję, później jeszcze Albanię czy Bośnię. W federalizacji upatrywano lek na całe zło wojen - konfliktów o granice i terytoria, jak i rywalizacji wielkich mocarstw. Jednocześnie, jak dochodziło już do krystalizowania się konkretnych koncepcji, partykularyzmy narodowe dawały o sobie znać i o ile porozumienia bilateralne miałyby szanse na urzeczywistnienie, to w grupie kilku partnerów osiagnięcie porozumienia, wydaje się, nie miałoby żadnych szans realizacji. Niemniej, dorobek XIX-wiecznej bałkańskiej myśli federacyjnej, połączonej z aspektami wolnościowymi, zapisał się w historii Europy jako pozytywna nieimperialna działalność polityczna. $\mathrm{Na}$ marginesie warto zauważyć, że dobrowolne zwiazki państw, z których żadne nie jest dominujące $w$ danym regionie, budowane $w$ opozycji lub bez zgody sąsiednich mocarstw, nie miały i nie mają większych szans na urzeczywistnienie. Współczesna Unia Europejska rozpoczynała funkcjonowanie wokół dominującego rdzenia francusko-niemieckiego, federacja bułgarsko-jugosłowiańska (komunistyczna) mogła powstać jedynie przy przyzwoleniu z ZSRR, a nie bez znaczenia był wpływ brytyjsko-amerykański. Drugim ważnym aspektem jest zgoda społeczna i elit politycznych przy budowaniu państwa federacyjnego; w budowaniu wspólnych organów państwowych łatwo bowiem narazić się na zarzut zdrady interesów państwowych. Dlatego budowanie państw związkowych jest procesem niezwykle skomplikowanym i delikatnym, wymagajacym szerokiego porozumienia.

Autorka wspomina koncepcje europejskich rządów emigracyjnych w czasie II wojny, plany i tkłady polsko-czechosłowackie czy grecko- 
-jugosłowiańskie, które oczywiście nie mogły być zrealizowane bez zgody głownych graczy na scenie politycznej, a już szczególnie bez akceptacji ZSRR. Sowieci mieli swoje koncepcje dotyczące urządzenia Europy Środkowo-Wschodniej, dla dużej części lokalnych polityków nieznane. Józef Stalin w okresie wyzwalania Bułgarii wyrażał swoja zgodę na połaczenie Bułgarii $z$ Jugosławią $w$ jeden organizm państwowy $i$ wlaśnie przełom 1944/1945 to pierwszy etap zbliżenia tych państw. Jednakże budowa silnego państwa komunistycznego nie była korzystna dla aliantów zachodnich i byli oni jeszcze władni wymóc na Stalinie powstrzymanie procesu zbliżenia. Autorka utrzymuje, że Stalin na początku 1945 roku musiał liczyć się ze zdaniem sojuszników i układ jugosłowiańsko-bułgarski chwilowo powstrzymał.

Poza rozdziałem wstępnym, praca opisuje cały proces zbliżania się Bułgarów i Jugosłowian do osiagnnięcia porozumienia federacyjnego. Bardzo szeroko i szczegółowo opisana jest kwestia macedońska, będąca przez długie lata kością niezgody pomiędzy tymi państwami słowiański$\mathrm{mi}^{3}$. Na całym temacie federacji ciażyła kwestia tożsamości narodowej Macedończyków. O ile w Macedonii Wardarskiej (część Jugosławii) jej mieszkańcy mieli silne tendencje autonomiczne i niezależnościowe, to w Macedonii Piryńskiej (część Bułgarii) większość poczuwała się do nacji bułgarskiej. Dlatego proces jednoczenia Macedonii w ramach federacyjnej Jugosławii (czyli połączenia obydwu części w ramach autonomicznej republiki ludowej) stwarzał niemałe problemy. Komuniści bułgarscy forsowali u siebie „macedonizm” nawet wbrew ludności Macedonii Piryńskiej, a jednocześnie proces formowania wspólnego tworu jugosłowiańsko-bułgarskiego pozostawał w zawieszeniu. Cały czas bowiem pozostawała kwestia: czy Bułgaria będzie przyjęta na zasadach 7 republiki (przy 6 jugosłowiańskich), czy połączenie nastapi na zasadzie 1:1. Na tej podstawowej kwestii problem federacji „rozbijał się" w rozmowach i działaniach polityków obydwu stron.

Znamierowska-Rakk szczegółowo opisuje dążenia obydwu stron prowadzące do osiagnięcia porozumienia, prezentując też postawy najważniejszych polityków wobec tych kwestii. Wytrwale przedstawia treści

${ }^{3}$ O sprawach macedońskich w Polsce pisze się w ostatnim czasie dosyć często: zob. A. Giza, Ziemie macedońskie na przelomie $X I X$ i $X X$ wieku, Szczecin 1996; I. Stawowy-Kawka, Historia Macedonii, Wroclaw 2000; I. Stawowy-Kawka (red.), Miejsce Macedonii na Balkanach, Kraków 2005; A. Malinowski, Kwestia macedonska w Bulgarii w latach 1878-1918, Toruń 2006. 
rezolucji podejmowanych na forum Komitetu Centralnego $B P R(k)^{4}$ i ich realizowanie. Niejednokrotnie podkreśla fakt zdecydowanej dominacji komunistów Tity w relacjach $\mathrm{z}$ "towarzyszami od Dymitrowa", co ci pierwsi byli w stanie skutecznie wykorzystywać. Komunistyczne partie w regionie nie mogły pochwalić się takim dorobkiem rewolucyjnym jak właśnie Tito; Bułgarzy zdawali sobie sprawę, że przejęcie władzy przez $\mathrm{BPR}(\mathrm{k})$ nastapiło jedynie dzięki radzieckim armiom, rozmowy dwustronne $\mathrm{z}$ Jugosławią nie były prowadzone jak równy z równym.

Georgi Dymitrow w 1946 roku zgodził się na „macedonizacje”” Macedonii Piryńskiej, do czego wykorzystywano nauczycieli, gazety, grupe teatralną i biblioteki, wszystko przysyłane $z$ Ludowej Republiki Macedonii. Połączenie dwóch części Macedonii miało poprzedzać utworzenie Federacji Słowian Południowych, do której obydwa państwa zbliżyly się po porozumieniach z 1947 roku. Apogeum zbliżenia południowosłowiańskiego autorka umieszcza od sierpnia 1947 r. do stycznia 1948 r.; przypomina prawie że „wiernopoddańcze" zachowanie Dymitrowa wobec dokonań Jugosławii prezentowane w czasie oficjalnej wizyty w Belgradzie i Zagrzebiu. Jednocześnie Jugosławia w tym okresie powoli i ostrożnie wycofuje się $\mathrm{z}$ coraz bliższego łączenia się z Bułgarią.

W ostatnim rozdziale opisano spotkanie kremlowskie z 10 lutego 1948 r., na którym Stalin brutalnie skrytykowal Dymitrowa i bardziej oględnie Jugosłowian, co było początkiem etapu rozbicia jedności sowiecko-jugosłowiańskiej. Warto podkreślić, że o formie federacji głos decydujacy miał Stalin i tak naprawdę tylko od niego zależało, jak porozumienie to będzie wyglądało. Autorka przypomina, jak sowiecki dyktator instrumentalnie traktowal powstawanie federacji, bardzo często zmieniając opinie i skłócając jednych $z$ drugimi. Być może roli Stalina wobec federacji powinien być w całości poświęcony jeden podrozdział; w układzie chronologicznym jego udział w przedsięwzięciu jednak rozmnwa się. Na lutowym spotkaniu Stalin wyraził oburzenie wobec polityki Belgradu prowadzacej do podporządkowywania Albanii, zakazał prowadzenia niezależnej polityki zagranicznej. Wysoką notę za wiarygodność wspomnień autorka wystawia Milovanovi Djilasowi, z któtego Rozmów ze Stalinem słusznie skorzystała ${ }^{5}$.

Problematyka zbliżania się komunistów bułgarskich i jugosłowiańskich nasuwa wrażenie, że Dymitrowowi bardzo zależało na porozumieniu z Tito, w którym widział kandydata na lidera ruchu komunistycznego

${ }^{4}$ Bułgarska Partia Robotnicza (komunistów).

${ }^{5}$ M. Dżilas, Rozmowy ze Stalinem, Paryż 1962. 
zdolnego stanowić konkurencję dla Stalina. Dymitrow zbyt długo przebywał w Moskwie, by nie zdawać sobie sprawy, że państwa demokracji ludowych będą sprowadzone do roli satelitów ZSRR, bez możliwości realizowania swoich interesów. Razem z Jugosłowianami Bułgarzy mogliby mieć większe pole manewru i siłę przebicia. Koncepcje dostosowywania komunizmu do miejscowych warunków - łączące się z wprowadzaniem komunizmu na swój sposób, bez kalkowania Zwiazku Radzieckiego - nie były w tym okresie (jeszcze przed jugosłowiańską schizmą) wyjątkowe. Szczególnie komuniści jugosłowiańscy i słowaccy, ale i grupy w innych krajach, nie spodziewały się gorsetu, jaki Stalin nałoży im po przejęciu przez nich pełni władzy. Tito był zbyt wyrazistą postacia nie zamierzał chylić przed Stalinem głowy. Dlatego w lutym 1948 roku wymówił się chorobą i nie pojechał do Moskwy. Autorka pisze, że Dymitrow „nie znajdując w sobie dość siły" móg jedynie po cichu solidaryzować się z Tito, zdradzając "podziw dla odwagi i rozmachu Tity" (s. 386). Dymitrow może nie tyle nie miał odwagi, co argumentów o sile i prężności komunistycznego ruchu w Bułgarii (argumenty te miał Tito), dlatego jedyne co mu zostawało to służalczość wobec Stalina. „Lew procesu lipskiego" o procesie dawno już zapomniał... Faktem też jest, iż Dymitrow wrócił do ojczyzny z ZSRR jako człowiek ciężko chory fizycznie i mocno nadłamany psychicznie przez stalinizm, z którym mimo pozorów nie utożsamiał się całkowicie. Imponował mu więc prężny, nięzależny i energiczny Tito. Jak wspominał ambasador Mieczysław Bibrowski, życzliwość Dymitrowa do Tity była aż nadto widoczna dla dyplomatów rezydujących w Belgradzie ${ }^{6}$.

W okresie 1947-1948 Dymitrow kilkakrotnie zmuszony byl przez Stalina do samokrytyki, tak w Moskwie jak i przed swoimi towarzyszami, głównie w kwestiach „nieudolnie” prowadzonej polityki zagranicznej. Na przykładzie Federacji Słowian Południowych, co doskonale ilustruje książka, można barwnie namalować obraz stalinowskiej polityki wobec satelitów.

Problem macedoński nie zniknął po 1948 roku, Znamierowska-Rakk przypomina o dalej prowadzonym procesie ,macedonizacji” w Ludowej Republice Bułgarii, co wydawałoby się bezcelowe; role „Piemontu” dla wszystkich części Macedonii nie mogła przecież pełnić część piryńska. Zatem nierozwiązany spór bułgarsko-jugosłowiański o przyszłą zjednoczoną Macedonię trwać miał dalej, a rozbudzone nadzieje polityków ma-

${ }^{6}$ Według wspomnień J. W. Borejszy z warsztatów naukowych prowadzonych dla studentów IH UW z M. Biborwskim. 
cedońskich jedynie podtrzymywały istnienie nieporozumień. Rozgrzane dysputy wokól kwestii trwały jeszcze w latach 70-tych i 80-tych, a i po powstaniu w 1991 roku niezależnej Republiki Macedonii kwestie sporne nie zostaly rozwiązane. Wystarczy tylko wspomnieć protekcjonalną politykę demokratycznej już Bułgarii wobec Macedonii, jak i sprzeciwy Grecji wobec nowego tworu państwowego, uzurpującego sobie prawo do historycznej greckiej nazwy i symboli.

W pracy Elżbiety Znamierowskiej-Rakk odczuwa się brak szerszych komentarzy i ocen dotyczaccych szans przetrwania i funkcjonowania zamierzanej Federacji Słowian Południowych. Wszystko wskazuje na to, że nie mialaby ona większych racji bytu w dhuższym okresie czasu. I nie chodzi tylko o to, że wszystkie komunistyczne federacje rozpadly się (ZSRR, Czechosłowacja, Jugosławia), ale partykularyzmy narodów nieznacznie tylko zbliżonych do siebie rozsadzają takie formy państwowe, a grupy nastawione separatystycznie mają zdecydowanie więcej nośnych argumentów na rzecz niezależnego bytu państwowego. Federacja Słowian Poludniowych na pewno byłaby państwem silnym, zdecydowanie dominującym na Bałkanach. Jednakże komunizm, który doprowadziłby do jej powstania, byłby jednocześnie pierwszym czynnikiem dezintegrującym. Wystarczy podać tu sam przykład federalnej Jugosławii. Komunizm wzbudzał u społeczeństwa niechęć do wspólnego państwa i wszystkie czynniki prowadzące w stronę jego rozbicia wydawały się do zaakceptowania. I jeszcze jeden czynnik - w Europie XX wieku z roku na rok coraz mocniejsze stawały się dążenia do prowadzenia niezależnego bytu państwowego przez najmniejsze nawet społeczności. A Półwysep Bałkański jest pod tym względem szczególny. „Bałkanizacja” jeszcze w XXI wieku trwa w najlepsze, o czym świadczą przykłady Kosowa i Czarnogóry.

Obszema praca Federacja Slowian ... zawiera jako załączniki mapy, które są niezwykle pomocne w trakcie czytania. $Z$ drugiej strony na poszczególne podrozdziały składają się zbyt duże połacie tekstu, umieszczenie odpowiednich podtytułów do poszczególnych partii tekstu byłoby pożyteczne i pozwalałoby na lepsze poruszanie się po poszczególnych zagadnieniach. W książce nie uniknięto pewnych powtórzeń i szczegółowego thumaczenia kwestii, wydawałoby się, zrozumiałych dla czytelnika. Ale poza tymi, w gruncie rzeczy drobnymi uwagami, wydaje się, że praca będzie służyła w poznawaniu najnowszej historii Bułgarii, a historykom w dalszych badaniach nad tematami bałkańskimi XX wieku. 